University of Miami Law School University of Miami School of Law Institutional Repository

Articles

Faculty and Deans

2012

\title{
Miami's Medical-Legal Partnership: Preparing Lawyers and Physicians For Holistic Practice
}

JoNel Newman

University of Miami School of Law, jnewman@law.miami.edu

Follow this and additional works at: https://repository.law.miami.edu/fac_articles

Part of the Health Law and Policy Commons, Legal Education Commons, and the Legal Profession Commons

\section{Recommended Citation}

JoNel Newman, Miami's Medical-Legal Partnership: Preparing Lawyers and Physicians For Holistic Practice, 9 Ind. Health L. Rev. 473 (2012).

This Article is brought to you for free and open access by the Faculty and Deans at University of Miami School of Law Institutional Repository. It has been accepted for inclusion in Articles by an authorized administrator of University of Miami School of Law Institutional Repository. For more information, please contact library@law.miami.edu. 


\title{
Miami's Medical-Legal Partnership: Preparing LaWyers and Physicians for Holistic Practice
}

\author{
JoNel Newman
}

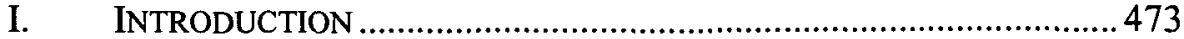

II. OVERVIEW OF MEDICAL-LEGAL PARTNERSHIPS ........................ 475

III. THE UNIVERSITY OF MIAMI'S EVOLVING MEDICAL-LEGAL PARTNERSHIP.

IV. AN INTERDISCIPLINARY CLINIC ..........................................478

A. Referral and Access to the Medical-Legal Clinic ....................478

B. The Clinical Model .............................................................. 479

V. LESSONS, POTENTIAL PITFALLS AND PROMISES ..........................480

\section{INTRODUCTION}

A fifty-one-year-old veteran, $\mathrm{Mr}$. $\mathrm{H}$ was hit by a speeding car while riding his motorcycle. While lying on the side of the road, he was forced to have an emergency, above-the-knee leg amputation. Two days later, he had to quit his job as a truck driver and apply for Social Security disability benefits to support himself. The Social Security Administration denied his claim twice. Mr. H became seriously depressed and even thought about taking his own life. He had no income, could not pay bills, and could barely afford to eat. Mr. H's doctors at the VA Hospital in Miami could not understand why Social Security denied his disability claim, and referred him to the on-site Medical-Legal Clinic. The lawyers and law students worked with the VA physicians in the Medical-Legal Clinic to put together evidence for his case that convinced a judge to bypass the typical two-year wait for a hearing and approve $\mathrm{Mr}$. H's claim immediately. ${ }^{1} \mathrm{Mr}$. H now

\footnotetext{
* Professor of Clinical Education, Director, Health and Elder Law Clinic, University of Miami School of Law. The author wishes to thank and acknowledge the contributions of the other medical and legal clinicians in the interdisciplinary clinic described below, including Panagiota Caralis, MD, JD, who gave the Clinic a home and her inspiration and dedication, Edwin Olsen, MD, JD, and the Clinic's Associate Director, Melissa Swain, JD, who makes everything work. Thanks are also due to Deans Patricia D. White and Patrick O. Gudridge of the University of Miami School of Law, and Deans Pascal J. Goldschmidt and Alex J. Mechaber of the Miller School of Medicine for their support of this program, to Jennifer Bard and the AALS Section on Law, Medicine, and Health Care for the opportunity to discuss these observations at the 2012 AALS Annual Meeting, to Tony Alfieri for thoughtful comments and guidance along the way, and to Susan Stefan and Courtney Campbell, both of whom provided valuable feedback.

1. The average amount of time it took to process a hearing request during fiscal year 2010 was 426 days. Frequently Asked Questions: How long does the hearing process normally take?, SOC. SEC. ADMIN., http://ssa-custhelp.ssa.gov/app/answers/detail/a_id/1160 (last visited June 1, 2012).
} 
receives monthly Social Security disability benefits and associated Medicaid health insurance coverage, which has reimbursed the hospital that first treated Mr. $\mathrm{H}$ for the catastrophic costs of Mr. H's emergency care and treatment resulting from the accident. Without the Medical-Legal Clinic's immediate intervention, $\mathrm{Mr}$. $\mathrm{H}$ would have waited approximately two years, if he survived, for a Social Security Administrative Law Judge to adjudicate his case.

Ms. M, a thirty-year-old veteran, suffered traumatic brain injury as a result of a bomb blast to her vehicle in Iraq. She came to the Medical-Legal Clinic because her condition resulted in cognitive impairments, and she no longer felt able to manage her financial affairs. She wanted her mother to be able to take care of her finances for her. Once the VA physicians in the Medical-Legal Clinic confirmed that Ms. M. had capacity to make these important decisions, the Clinic prepared a financial durable power of attorney for her, authorizing her mother to manage Ms. M's accounts, and petitioned the Florida Circuit Court's Probate Division to designate Ms. M's mother as her future guardian in case her condition worsened. The Clinic also completed a living will and designated a health care surrogate for her. At each step in the process, Ms. $M$ had access to legal and medical clinicians who could explain both the legal import of the documents and the medical aspects of the termination of life prolonging treatments and loss of capacity. Having these documents in place gave Ms. M tremendous peace of mind and allowed her to concentrate on her recovery.

These are only two representative examples of the groundbreaking interdisciplinary Medical-Legal Clinic that the University of Miami has pioneered with the VA Medical Center in Miami.

The University of Miami's Law School and Miller School of Medicine have for much of the last decade explored innovative and collaborative ways to educate future professionals and to deliver quality care to underserved populations. In 2011 we experimented with a pilot course that brought faculty and students from both disciplines together for a weekly hospital-based clinical practicum supplemented with interdisciplinary didactic sessions. The interdisciplinary clinic was designed to foster collaborative team-based interdisciplinary work to identify, assess, and treat the medical and legal needs of patient-clients. The purpose of the didactic sessions was to provide clinical students from the law school and the medical residents cross-training in each other's disciplines to the extent necessary to engage in the joint clinical practice. ${ }^{2}$

The interdisciplinary collaboration between the schools has now grown into a joint clinic and clinical rotation offering for medical students. ${ }^{3}$

2. Univ. OF Miami LaW SCH., MEDICAL/LEgal INTERdISCIPLINARY ClINIC, LAW 744 COURSE DESCRIPTION (Spring 2011) (on file with author).

3. Univ. of Miami Miller Sch. OF Med., MDR 966, Clinical Rotation DESCRIPTION (2011-2012) (on file with author). 
We also offer a four-year pathway of emphasis, or area of scholarly concentration, for medical students interested in health law. ${ }^{4}$ This essay will briefly describe our interdisciplinary Medical-Legal Clinic, and discuss some of the lessons we have learned from our collaborations. It will conclude with a discussion of the promise we believe academically-based medical-legal partnerships, and especially clinics, hold for the education of tomorrow's lawyers and physicians.

\section{OVERVIEW OF MEDICAL-LEGAL PARTNERSHIPS}

Across the country, Medical-Legal Partnerships ("MLPs") are a growing trend. ${ }^{5}$ This service delivery model integrates legal assistance as a "vital component of healthcare." As the Medical-Legal Partnership for Health Act, introduced by Senator Harkin in the 112th Congress recognizes, "[f]ormally integrating medical and legal professionals in the health setting can more effectively address the health needs of vulnerable populations and ultimately reduce health disparities."7 The National Center for MedicalLegal Partnership reports 87 programs in its network at 225 hospitals and health centers throughout the country. ${ }^{8}$ The focus of these partnerships is primarily on addressing the social determinants of health for low income and vulnerable populations.

Under the MLP model, attorneys work with front-line health center staff to screen for health-related legal problems, such as family matters (divorce, custody/visitation, domestic violence), housing problems (eviction, habitability, utility advocacy), special education advocacy, immigration issues, disability issues, end-of-life care, employment instability, receipt of public benefits (health insurance, disability/supplemental security income, Social Security Income), food security concerns, and additional problems and situations that lead to stress and cause or exacerbate health problems. Working with social

4. Maya Bell, New Pathway in Health Law Further Personalizes Medical Education, U. MIAMI MiLlER SCH. OF MED. (Jan. 5, 2012), http://med.miami.edu/news/new-pathway-inhealth-law-further-personalizes-medical-education.

5. Erik Eckholm, When Doctor Visits Lead to Legal Help, N.Y. TIMES, Mar. 23, 2010, at A15, available at http://www.nytimes.com/2010/03/24/us/24legal.html.

6. Ellen Lawton et al., Medical-Legal Partnership: A New Standard of Care for Vulnerable Populations, in POVERTY, HEALTH AND LAW 74 (Elizabeth Tobin Tyler et al. eds., 2011). 2011).

7. S. 1609 , 112th Cong. $\S 2(a)(4)$ (2011); CoNG. REC. S5906 (daily ed. Sept. 22,

8. Lawton, supra note 6 , at 89. 
workers and case managers, MLP staff help to secure housing assistance, Social Security Income, public insurance, early intervention programs for children with special needs, and other public benefits. ${ }^{9}$

The delivery of legal services in the health care setting may improve patient health outcomes, ${ }^{10}$ increase revenue for health providers, ${ }^{11}$ and reduce overall health care costs by reducing the number of emergency room visits and hospitalizations. ${ }^{12}$

\section{THE UNIVERSITY OF MIAMI'S EVOLVING MEDICAL-LEGAL PARTNERSHIP}

The Health and Elder Law Clinic and its predecessor, the Community Health Rights Education Clinic, were originally founded by Anthony Alfieri based on the cross-disciplinary, medical-legal model of community advocacy developed by Professors Gary Bellow and Jeanne Charn at Harvard Law School's WilmerHale Legal Services Center in the 1980s. ${ }^{13}$ The Harvard project conducted "legal check-ups" at the Brigham and Women's Hospital ambulatory care waiting room. ${ }^{14}$ Lawyers assessed the client's profile for potential eligibility for various public benefits. ${ }^{15}$ Miami Law's

9. Peter Shin et al., Medical-Legal Partnerships: Addressing the Unmet Legal NeEds of HEalth CENTER PATIENTS 5 (2010), available at http://www.gwumc.edu/ sphhs/departments/healthpolicy/dhp_publications/pub_uploads/dhpPublication_60CE05B15056-9D20-3D0F917148C7E929.pdf.

10. Pascoe Pleasence et al., The Health Cost of Civil-Law Problems: Further Evidence of Links Between Civil-Law Problems and Morbidity, and the Consequential Use of Health Services, 5 J. EMPIRICAL LEGAL STUD. 351, 365-67 (2008); David I. Schulman et al., Public Health Legal Services: A New and Powerful Vision, 15 GEO. J. ON POVERTY L. \& POL'Y 729, 764-70 (2008); RANDYE RETKIN ET AL., THE IMPACT OF LEGAL INTERVENTIONS ON CANCER SURVIVORS (2007), available at http://www.bc.edu/content/dam/files/schools/law sites/library/pdf/content/tremblay schulman/2007-01-00.Retkin\%20et\%20al.pdf.

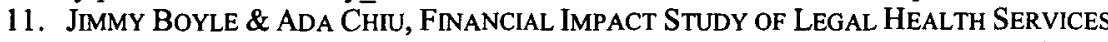
TO NEW YORK CITY HOSPITALS (2009), available at http://legalhealth.org/docs/ cost_benefit_final_report.pdf.

12. Justin Fitzgerald, The Future of Health Care: Medical-Legal Partnership for Health Act, BOS. HEALTH L. REP., Winter 2011, at 13 (describing a pilot study in Boston that shows a fifty percent decrease in ER visits following a Medical-Legal intervention).

13. Anthony Alfieri, (Un)covering Identity in Civil Rights and Poverty Law, 121 HARV. L. REV. 805, 821 n.50 (2008) (citing Gary Bellow \& Jeanne Charn, Paths Not Yet Taken: Some Comments on Feldmans Critique of Legal Services Practice, 83 GEO. L.J. 1633, 1649 n.54, 1659-63 (1995) (describing the Medical-Legal Services Project)); Anthony Alfieri, Teaching Ethics/Doing Justice, 73 FORD. L. REV. 851, 860-61 (2004) (describing the Community Health Rights Education Clinic).

14. Marybeth Musumeci, Augmenting Advocacy: Giving Voice to the Medical-Legal Partnership Model in Medicaid Proceedings and Beyond, 44 U. MICH. J.L. REFoRM 857, 885 (2011).

15. Id.; see also Jeffrey Selbin \& Mark Del Monte, A Waiting Room of Their Own: The Family Care Network as a Model for Providing Gender-Specific Legal Services to 
Health and Elder Law Clinic began by providing similar legal check-ups, analyzing and assessing eligibility for various public benefits and entitlements, and providing other on-site legal services, with particular emphasis on advance directives, to patients and families in the School of Medicine's Family Care and Prenatal HIV Clinics and the Pediatric Mobile Clinic.

In 2005 these services were expanded to the Adult HIV Clinic at the University of Miami Medical School and Jackson Memorial Hospital. The Health and Elder Law Clinic conducted office hours on-site four days a week for a patient base of several thousand. (Miami-Dade County has the third-highest serio-prevalence rate in the nation). ${ }^{16}$ The Clinic also began offering services to patients at Jefferson Reaves Sr. Health Center, which serves a large, multi-cultural, low-income population in Miami's historically black neighborhood of Overtown. ${ }^{17}$

The legal services offered by the Law Clinic include representation in Social Security and other public benefits cases, as well as securing Medicaid and other insurance. The Law Clinic also provides drafting and document services for advance directives such as wills, living wills, health care surrogacy, pre-need guardianships and guardianships. In addition, the Law Clinic represents clients in landlord-tenant and immigration cases that have a health-related nexus. Since 2005 the 113 Miami law students who have rotated through the Health and Elder Law Clinic have, under the supervision of the Clinic's legal staff, provided legal services in more than 1000 cases. $^{18}$

The Clinic strives to provide "holistic" legal services to the client population it serves by addressing all the clients' legal needs. ${ }^{19}$ This model of service delivery is especially important for a client population that may have no other alternative for legal services. ${ }^{20}$ The problems faced by impoverished and health-impaired clients are often interconnected, as "[p]eople's lives are not neatly compartmentalized." derstanding that we began to explore a more interdisciplinary clinical model, one that truly integrated medical and legal services not only at a single point of entry, but as a fully integrated care and treatment model.

Women with HIV, 5 DUKE J. GENDER L. \& POL'Y 103, 124-27 (1998) (describing the use of this model as an integrated part of women's HIV care).

16. JoNel Newman, Re-conceptualizing Poverty Law Clinical Curriculum and Legal Services Practice: the Need for Generalists, 34 Fordham URB. L.J. 1303, 1319 (2007).

17. Community Health Centers of Excellence, UNITED HEALTH Found., http://www. unitedhealthfoundation.org/Grants/GrantsHealthCenters.aspx (last visited May 21, 2012).

18. Clinic Records, 2005-2012, on file with author.

19. Newman, supra note 16 , at $1312-16$.

20. Katherine Mattes, The Tulane Criminal Law Clinic: An Evolution into a Combined Individual Client and Advocacy Clinic, 18 CLINICAL L. REV. 77, 93 (2011).

21. Marsha M. Mansfield \& Louise G. Trubek, New Roles to Solve Old Problems: Lawyering for Ordinary People in Today's Context, 56 N.Y.L. SCH. L. REV. 367, 372 (2011). 


\section{AN INTERDISCIPLINARY CLINIC}

\section{A. Referral and Access to the Medical-Legal Clinic}

In the Spring of 2011, working with medical faculty with clinical responsibilities in the Miami VA Healthcare System, we were able not only to offer services to veterans through the traditional MLP model, but to actually operate a joint clinic. Every Wednesday, medical residents, medical clinicians, law students and clinical legal faculty assembled in one of the Miami VA's outpatient clinics. Patients, referred by their social workers, were booked into the clinic and saw a medical and legal clinician at the same appointment. We had previously informed the VA social workers about the types of matters the Medical-Legal Clinic was best suited to handle, and we provided a referral form for the patient with check boxes listing these matters. ${ }^{22}$ We also had space for social workers to write in other issues, and they frequently did.

The referral form, and the referral process in itself, generated a somewhat unexpected opportunity for interdisciplinary dialogue and education. The lawyers in the partnership had to train the social work staff and medical personnel about what types of legal interventions were possible for a patient, and also about what types were recommended and why. When we started the Clinic, we received a high number of referrals requesting that we establish a guardianship over patients, often elderly, who had lost some mental capacity and needed a family member or other caretaker to manage their financial affairs and make living arrangements for them. In some instances a guardianship was the recommended outcome for the patient because the individual no longer possessed sufficient mental capacity to make any decisions. But for many others, the legal needs of the patient could be met through a simple durable power of attorney instrument that avoided a lengthy and expensive court process and better preserved the patient's dignity. ${ }^{23}$ Our discussions with referring social workers in the context of individual cases resulted in our law students creating an entire training module for the social work staff at the hospital about the various advance directives available to patients and how social workers could assist patients in making enforceable long-term decisions before an urgent situation arose, and before

22. The matters we identified and encouraged referrals for included the full range of advance directives and permanency planning documents (wills, living wills, durable power of attorney, health care surrogate, funeral directives, designation of pre-need guardianship, etc.), disability benefits cases, other public benefits cases, Medicare and Medicaid issues and housing. Referral form, on file with author.

23. For a discussion of the drawbacks of the guardianship process, see Leslie Salzman, Rethinking Guardianship (Again): Substituted Decision Making as a Violation of the Integration Mandate of Title II of the Americans with Disabilities Act, 81 U. COLO. L. REv. 157 (2010). 
the patient lost the capacity to make important decisions. ${ }^{24}$

\section{B. The Clinical Model}

In the Medical-Legal Clinic, when patients presented after having been referred by their social workers, and after authorizing the referral and access to their chart, they were booked into the outpatient clinic like any other patient, and taken to a medical examination room. Before the patient was seen by the medical and legal clinicians, the medical staff and clinical supervisors reviewed the patient's chart to familiarize themselves with any medical issues that might arise in the encounter. Legal clinicians reviewed the referral forms identifying the legal issue and the relevant legal forms and documents. To continue with the example of a referral to prepare various advance directives, if a patient was seen because he or she had requested a will, a living will, health care surrogacy and/or a durable power of attorney, ${ }^{25}$ then the medical clinician's chart review would focus on any questions about mental capacity, undue influence by a family member or other individual, and whether there were any previously-recorded advance directives in the patient's chart. ${ }^{26}$ The legal clinicians would prepare and bring with them a questionnaire designed to facilitate discussion about the patient's desires with respect to advance directives, as well as the forms, which provided a starting point to prepare the requested documents. ${ }^{27}$ The medical and legal clinicians then conferred with each other, with the legal clinicians explaining to the medical residents what the various forms accomplished, and the medical clinicians providing an overview of the patient's history and any relevant medical concerns. The medical and legal clinicians then visited with the patient. First, they confirmed that the patient's legal need was for advance directives. ${ }^{28}$ Then the medical resident or fellow would assess the patient's decision-making capacity while the law

24. Ashley DeWelde \& David Berk, PowerPoint Presentation: Planning for the Future: Helping Patients Make Enforceable Long Term Decisions (2011) (on file with author).

25. These were the most common advance directives requested and prepared.

26. The VA Healthcare System laudably incorporates its own version of the living will and health care surrogacy documents into a patient's chart, and all healthcare providers in its system are trained to look for and rely on them. See VA Form 1-0137: VA Advance Directive, DEP'T OF VETERANS AFFAIRS, http://www.va.gov/vaforms/medical/pdf/vha-10-0137fill.pdf (last modified Mar. 2011).

27. In Florida, where our Clinic practices, some advance directive forms are prescribed or recommended by Florida Statutes or administrative agency, such as the living will, Fla. Stat. Sec. 765.303 (suggested form of a living will), and the Do Not Resuscitate Order, DNRO Form 1896, Florida Dept. of Health (required form). Others, such as the will and the durable power of attorney, are fairly routine, and can often be adapted for each individual from a formulaic starting place.

28. Sometimes, though not often, the patient's needs and expectations did not match the referral form. Additional legal needs often surfaced during the course of the patient encounter. For the purposes of illustrating the clinical model, I am using a typical case with a straightforward issue in which neither of those things occurred. 
student clinician, under the direction of supervising legal faculty, assisted the patient in determining what instructions the patient wanted to give healthcare providers, family, and others. The patient/client care was greatly enhanced by the interdisciplinary nature of the Clinic. A typical patient with an end-stage medical condition who wished to create a living will, for example, had the advantage of having an explanation of what he could expect to encounter medically given his particular condition, and how the various choices he might make concerning life-sustaining treatment would affect him individually, while he simultaneously had access to a legal clinician who could explain the various legal requirements and consequences of the documents, and could adjust the language to tailor the documents to meet the patient's specific needs and wishes.

Following the patient encounter, and while the patient waited in the examination room, the medical resident or fellow and the law student clinician presented the case to the supervising faculty, and the group worked together to devise and begin to execute a "treatment plan." In an uncomplicated advance directive case such as that described above, the case round would involve making a chart note regarding competency and documenting the encounter along with the patient's preferences so that there was a record of the express wishes before the final documents were created, a discussion of what documents needed to be created to meet the patient's needs, and a plan for finishing them and getting them executed and filed in the appropriate places. The clinicians would then be dispatched back to the patient's room to discuss the plan and make follow-up arrangements. However, not all cases followed such an uncomplicated trajectory, and in some circumstances we found that it was the complicated issues that produced the most memorable outcomes and the most educational experiences for the clinical students, residents, and participating faculty.

\section{LESSONS, POTENTIAL PITFALLS AND PROMISES}

Patient care and outcomes are improved by this holistic service delivery model. Indeed, in some cases a successful outcome could not have occurred without the interdisciplinary clinical model. One such case involved a stroke victim with aphasia, a condition resulting from damage to the part of the brain that controls language. The fifty-four-year old patient was unable to speak, suffering from severe expressive and receptive deficits consistent with global aphasia. She had no advance directives in place, such as a durable power of attorney, that would permit a family member to take care of her urgent legal and financial matters, including a mortgage foreclosure and the need to contract, and pay for, her placement in a skilled nursing facility. In this case, the interdisciplinary treatment team-lawyers, physicians, and a speech pathologist - was able to create an assessment tool and methodology to determine the patient had capacity to make decisions, to document that fact, and to create a series of images that permitted the pa- 
tient to communicate her desires and to appoint a family member to make and execute financial and legal documents on her behalf. ${ }^{29}$ Without the interdisciplinary medical-legal intervention, the patient would likely have been declared incompetent by the state and appointed a guardian to make all her decisions. ${ }^{30}$

Significant differences-cultural and regulatory-exist between the medical and legal professions, offering potential pitfalls as well as rich educational promise. Continuing to utilize advance directives as an example, we did not immediately agree in several cases about a patient's mental capacity to make decisions. A predictable pattern emerged in cases in which capacity was a close question. Medical professionals, students and residents were far more likely to question a patient's mental capacity to make decisions. Especially, it seemed to the lawyers and law students, when they believed the patient was not making the healthiest choice, or the choice medical professionals deemed to be in the patient's best interests. On the other hand, the lawyers and law students almost invariably argued passionately in favor of a patient's "right" to autonomy and self-direction, even when the patient made poor choices, in the close cases. The lawyers suspected the physicians of paternalism, ${ }^{31}$ while the physicians wondered if the lawyers were naïve and irresponsible in advocating, for example, for the restoration of financial control to an impaired patient who was likely to purchase pornography and cigarettes when the patient suffered from COPD and had been a poor manager of his money. ${ }^{32}$

The interdisciplinary case round was an excellent vehicle for uncovering, identifying, and confronting these different predilections. Once we were able to engage in a productive discussion about these distinct approaches, the different professional learners at the table gained significant insight into the formation of professional identity in their own profession as well as the other. Medical learners were often surprised to learn that rules governing lawyer conduct permit lawyers a great deal of discretion in making their own judgments about a client's capacity, and in advocating on be-

29. Ilyas Sayeg et al., An Interdisciplinary Approach for Assessing Capacity and Communicating Consent in Aphasic Patient, Abstract \#1408, INT'L CONF. ON CoMM. IN HEALTHCARE, Summer 2011, at 165, available at http://www.aachonline.org/resource/ resmgr/icch/postersfinal.pdf.

30. Bell, supra note 4.

31. See, e.g., Ben A. Rich, Medical Paternalism v. Respect for Patient Autonomy: The More Things Change The More They Remain the Same, 10 MiCH. ST. U. J. MED. \& L. 87 (2006).

32. In this case, the law students succeeded in restoring the patient's access to his own funds. The funds had previously been diverted to an appointed professional agent who charged for her services and had restricted the patients access to his funds, creating and depositing into a savings account over his objections and repeated requests to be able to spend his own money. After a robust discussion in case rounds, the medical team supported this request, and assisted by providing competency evaluations. Case on file with author. 
half of clients whose mental disabilities might affect their judgment. ${ }^{33}$ Medical students were not prepared for what they viewed as the lawyers' almost single-minded dedication to an individual client without regard to broader societal concerns. ${ }^{34}$ The legal learners were equally surprised to learn not only of the physician's duty to report abuse or neglect, ${ }^{35}$ even when that violated a patient's trust and confidentiality, but of the physician's understanding of his or her professional duties as encompassing questions of broader public health, which might take precedence over the physician's loyalty to any individual patient. ${ }^{36}$

The interdisciplinary clinic enhanced the law students' and the physicians' skill development in team-delivered care, responsiveness to community and public needs, and inter-professional work. These areas have been identified by the recent Carnegie Foundation reports on medical and legal education as areas to be strengthened and improved. ${ }^{37}$ Interdisciplinary clinical practice, and the seminar component that accompanies the clinical immersion, is ideally suited to these challenges. When we began the joint seminar classes, the medical students and residents routinely revealed that they were mistrustful of the legal profession, sometimes even calling lawyers "the enemy." The law students were surprised to be viewed so dimly, and had uninformed assumptions about physicians that were often untrue. When the curtain was pulled back, and each discipline received some crosstraining, in both the didactic sessions and through the case rounds in individual patient care, each set of learners gained respect, appreciation, and a much better understanding of how each profession approaches problems, patients, and clients. Medical and legal learners emerged with better-

33. See, e.g., ABA COMm'N ON LAW \& AGING, Assessment of Older Adults With DiMINISHED CAPACITY: A HANDBOOK FOR LAWYeRS (2005); MOdel RULES OF PROF'L CONDUCT R. 1.14 (b) and cmts. 1, 6 (2010).

34. See, e.g., Wendy E. Parmet, Populations, Public Health, and the Law 2, 30 (2009) (noting that while "public health focuses on the interests of populations, lawyers are expected to represent the interests of individual clients," and arguing that lawyers should undertake more "population-based legal analysis").

35. FLA. STAT. $§ 39.201$ (2011) (physician mandatory reporting of suspected child abuse and neglect); FLA. STAT. § 415.1034 (2011) (physician mandatory reporting of suspected elder abuse, neglect and exploitation).

36. See, e.g., American Medical Ass'n, Rpt. of the Council on Ethical and Judicial Affairs, 4-I-06, available at: http://www.ama-assn.org/resources/doc/ethics/ceja_4i06.pdf (discussing widespread broad interpretation of the Tarasoff doctrine (Tarasoff $v$. Regents of University of California, 17 Cal. 3d 425 (1976)), to justify the disclosure of confidential information when it can avert harm to a third party); Micah Berman, A Public Health Perspective on Health Care Reform, 21 HealtH MATRIX 353, 355-56 (2011); Alison Patrucco Barnes, Beyond Guardianship Reform: A Reevaluation of Autonomy and Beneficence for a System of Principled Decision-Making in Long Term Care, 41 EMORY L.J. 633, 669-74 (1992).

37. Molly Cooke et al., Educating Physicians: A CAll for Reform of Medical SCHOOL AND RESidenCy 25, 56-58, 62-64 (2010); William M. Sullivan ET al., EdUCATING LAWYERS: PREPARATION FOR THE Profession OF LAW 180-82, 192 (2007). 
formed ethical and professional identities of their own. ${ }^{38}$

The Medical-Legal Clinic offers unique and cutting-edge opportunities for research and study. In addition to improved patient care and rich educational experiences, an academically-based Medical-Legal Clinic offers a unique laboratory for research and study. To date, there is a "paucity" of studies that gather and assess available data on the economic and other measurable benefits of an interdisciplinary Medical-Legal Clinic or of Medical-Legal Partnerships generally. ${ }^{39}$ We are presently working with the Department of Epidemiology and Public Health at the University of Miami Miller School of Medicine to investigate and report on how our Partnership impacts patient outcomes, public health, health care costs, and educational outcomes for the participating students. We look forward to reporting the results of these studies in the future.

38. For a lengthy discussion of the benefits of this cross training, including reducing "distrust, fear and antagonism," between the two professions, see Elizabeth Tobin Tyler, Allies not Adversaries: Teaching Collaboration to the Next Generation of Doctors and Lawyers to Address Social Inequality, 11 J. HEALTH CARE L. \& POL'Y 249, 249-50 (2008) (internal citation omitted).

39. Lauren Abel \& Susan Vignola, Economic and Other Benefits Associated with the Provision of Civil Legal Aid, 9 SEATTLE J. Soc. Just. 139, 140 (2010). 